\title{
Genetic characterization of antimicrobial resistance of Shigella flexneri 1c isolates from patients in Egypt and Pakistan
}

\author{
Salwa F Ahmed ${ }^{1 *}$, John Klena ${ }^{1}$, Tupur Husain ${ }^{1}$, Jesse Monestersky ${ }^{1}$, Amel Naguib $^{2}$ and Momtaz O Wasfy ${ }^{1}$
}

\begin{abstract}
Background: Shigella flexneri serotype 1c emerged as a critical isolate from children in Egypt and Pakistan. The pattern of antimicrobial susceptibility (AMS) and resistance genes of this serotype have yet to be characterized.

Findings: Sixty nine S. flexneri 1c isolates isolates were identified from both Egypt $(n-46)$ and Pakistan $(n=23)$ and tested for AMS by disk diffusion method and minimal inhibitory concentrations were also determined. Isolates were genotyped by pulsed field gel electrophoresis (PFGE) and five relevant resistance genes (bla $\mathrm{TEM}_{\mathrm{T}}$, bla $\mathrm{S}_{\mathrm{SH} \text {, }}$, bla $\mathrm{OXXA}_{\mathrm{A}}$, sull and sullI) were detected by polymerase chain reaction (PCR) and confirmed by DNA sequencing. High resistance was observed in all isolates for ampicillin (AM >96\%); trimethoprim-sulphamethoxazole and tetracycline (>88\%). Most AM-resistant isolates from Egypt (70\%) harbored bla expressed bla OXA. All isolates were closely related by PFGE, irrespective of source or time of collection. The sulll gene was present in 100\% of isolates from pediatric cases in Egypt, $65 \%$ of Pakistan isolates, and $53 \%$ of isolates from older Egyptian patients.

Conclusions: While different Shigella serotypes gathered in specific genotypic groups, 1c serotype isolates formed multiple clusters. Although AMS was considerably high to most commonly used drugs, genetic determinants were variable between countries over time. The data stress the need for a more careful selection of antibiotics in the treatment of shigellosis.
\end{abstract}

Keywords: S. flexneri 1c, Genetic diversity, Antibiotic resistance, Oxa1, PFGE, Egypt, Diarrhea, Pakistan

\section{Findings}

While Shigella sonnei is the main cause in industrialized countries, S. flexneri is predominant in developing countries (particularly serotype 2a) [1-4]. In a recent study, $S$. flexneri serotype $1 \mathrm{c}$ emerged as an important isolate (17\%) in three pediatric populations in Egypt [5]. The isolates were highly resistant to AM, tetracycline and sulfatrimethoxazole, with some showing simultaneous resistance to two or more antibiotics (multi-drug resistance phenotypes, MDR). Outside Egypt, this serotype has been described in Southeast Asia and the Indian subcontinent [5-8]. Also, many untypeable S. flexneri isolates from Pakistan belonged to serotype 1c [9]. The purpose of the present study was to characterize this

\footnotetext{
* Correspondence: salwa.fouad.eg@med.navy.mil

${ }^{1}$ Research Science Directorate, United States Naval Medical Research Unit No. 3, Cairo, Egypt

Full list of author information is available at the end of the article
}

serotype in a collection of isolates from Egypt and Pakistan for phenotypic and molecular markers of resistance to $\beta$-lactams and sulfonamides.

A total of $46 \mathrm{~S}$. flexneri serotype 1c isolates from Egypt were used; 10 from pediatric patients (EP, $<5$ years) examined between 1990 and 1994, 17 between 2000 and 2004 and 19 between 2001 and 2003. The last group came from non-pediatric patients (NEP; 9-19 years). Nineteen isolates were also obtained between 2002 and 2004 from Pakistani pediatric (PP) clinics located in the urban slums of Karachi $[9,10]$. All isolates were cultured from rectal swabs and/or stool samples and identified at NAMRU-3 using standard microbiological and biochemical procedures [11]. Informed consents were obtained from all involved adults and guardians of minors. The study was approved by the Institutional Review Board (IRB Protocol No 96) of NAMRU-3, in compliance with Helsinki Declaration and US Federal regulations gover- 
Table 1 Antibiotic resistance profile of S. flexneri 1c isolates from Egypt and Pakistan using both disk diffusion and E-test methods

\begin{tabular}{|c|c|c|c|c|c|c|c|c|c|c|c|c|c|c|c|c|c|c|c|c|c|c|c|c|c|c|c|c|c|c|}
\hline \multirow[t]{2}{*}{ Antibiotics } & \multicolumn{3}{|c|}{$A M^{1}$} & \multicolumn{3}{|c|}{$\mathrm{C}$} & \multicolumn{3}{|c|}{ TE } & \multicolumn{3}{|c|}{ SXT } & \multicolumn{3}{|c|}{ CET } & \multicolumn{3}{|c|}{ CIP } & \multicolumn{3}{|c|}{ CRO } & \multicolumn{3}{|c|}{ FEB } & \multicolumn{3}{|c|}{ CAZ } & \multicolumn{3}{|c|}{ CTX } \\
\hline & $\mathrm{S}^{2}$ & 1 & $R$ & $S$ & 1 & $\mathbf{R}$ & $S$ & 1 & $\mathbf{R}$ & $S$ & 1 & $\mathbf{R}$ & $S$ & 1 & $\mathbf{R}$ & $\mathrm{S}$ & 1 & $\bar{R}$ & $S$ & 1 & $\mathbf{R}$ & $\mathrm{s}$ & 1 & $\mathbf{R}$ & $S$ & 1 & $\mathbf{R}$ & $\mathrm{S}$ & 1 & $\bar{R}$ \\
\hline $\begin{array}{c}\mathrm{CLSI} \text { MIC }{ }^{3} \\
\text { breakpoints } \mu \mathrm{g} / \mathrm{mL}\end{array}$ & $\leq 8$ & 16 & $\geq 32$ & $\leq 8$ & 16 & $\geq 32$ & $\leq \underline{4}$ & 8 & $\geq 16$ & $\begin{array}{l}\leq 2 / \\
38\end{array}$ & & $\begin{array}{l}\geq 4 / \\
76\end{array}$ & $\leq 8$ & 16 & $\geq 32$ & $\leq 1$ & 2 & $\geq 4$ & $\leq 1$ & 2 & $\geq 4$ & $\leq \underline{8}$ & 16 & $\geq 32$ & $\leq \underline{4}$ & 8 & $\geq 16$ & $\leq 1$ & 2 & $\geq 4$ \\
\hline $\begin{array}{c}\text { EP }^{4} \text { isolates }(n=10) \\
(1990-1994)\end{array}$ & 0 & 0 & $\begin{array}{c}10 \\
(100)^{7}\end{array}$ & 0 & 0 & $\begin{array}{c}10 \\
(100)\end{array}$ & 0 & 0 & $\begin{array}{c}10 \\
(100)\end{array}$ & $\begin{array}{c}6 \\
(60)\end{array}$ & $\begin{array}{c}2 \\
(20)\end{array}$ & $\begin{array}{c}2 \\
(20)\end{array}$ & 0 & $\begin{array}{c}2 \\
(20)\end{array}$ & $\begin{array}{c}8 \\
(80)\end{array}$ & $\begin{array}{c}10 \\
(100)\end{array}$ & 0 & 0 & $N D^{8}$ & & & ND & & & ND & & & ND & & \\
\hline $\begin{array}{l}\text { EP isolates }(n=17) \\
\quad(2000-2004)\end{array}$ & $\begin{array}{l}1 \\
(6)\end{array}$ & 0 & $16(94)$ & $\begin{array}{l}16 \\
(94)\end{array}$ & 0 & $1(6)$ & $\begin{array}{c}2 \\
(12)\end{array}$ & 0 & $\begin{array}{c}15 \\
(88)\end{array}$ & $\begin{array}{c}2 \\
(12)\end{array}$ & 0 & $\begin{array}{l}15 \\
(88)\end{array}$ & $1(6)$ & $\begin{array}{c}14 \\
(82)\end{array}$ & $\begin{array}{c}2 \\
(12)\end{array}$ & $\begin{array}{c}17 \\
(100)\end{array}$ & 0 & 0 & $\begin{array}{c}17 \\
(100)\end{array}$ & 0 & 0 & $\begin{array}{c}17 \\
(100)\end{array}$ & 0 & 0 & $\begin{array}{c}17 \\
(100)\end{array}$ & 0 & 0 & $\begin{array}{c}17 \\
(100)\end{array}$ & 0 & 0 \\
\hline $\begin{array}{l}\operatorname{NEP}^{5} \text { isolates }(n=19) \\
\quad(2001-2003)\end{array}$ & 0 & 0 & $\begin{array}{c}19 \\
(100)\end{array}$ & $\begin{array}{l}16 \\
(84)\end{array}$ & 0 & $3(16)$ & 0 & 0 & $\begin{array}{c}19 \\
(100)\end{array}$ & $\begin{array}{c}2 \\
(11)\end{array}$ & 0 & $\begin{array}{l}17 \\
(89)\end{array}$ & $1(5)$ & $\begin{array}{l}12 \\
(63)\end{array}$ & $\begin{array}{c}6 \\
(32)\end{array}$ & $\begin{array}{c}19 \\
(100)\end{array}$ & 0 & 0 & $\begin{array}{c}19 \\
(100)\end{array}$ & 0 & 0 & $\begin{array}{c}19 \\
(100)\end{array}$ & 0 & 0 & $\begin{array}{c}19 \\
(100)\end{array}$ & 0 & 0 & $\begin{array}{c}19 \\
(100)\end{array}$ & 0 & 0 \\
\hline $\begin{array}{l}\mathrm{PP}^{6} \text { isolates }(\mathrm{n}=23) \\
(2002-2003)\end{array}$ & $\begin{array}{l}1 \\
(4)\end{array}$ & & $22(96)$ & $\begin{array}{c}4 \\
(17)\end{array}$ & & $\begin{array}{c}19 \\
(83)\end{array}$ & $2(9)$ & & $\begin{array}{l}21 \\
(91)\end{array}$ & $1(4)$ & & $\begin{array}{l}22 \\
(96)\end{array}$ & $\begin{array}{c}6 \\
(26)\end{array}$ & $\begin{array}{l}17 \\
(74)\end{array}$ & 0 & $\begin{array}{l}10 \\
(100)\end{array}$ & 0 & 0 & $\begin{array}{l}23 \\
(100)\end{array}$ & 0 & 0 & $\begin{array}{c}23 \\
(100)\end{array}$ & 0 & 0 & $\begin{array}{c}23 \\
(100)\end{array}$ & 0 & 0 & $\begin{array}{l}23 \\
(100)\end{array}$ & 0 & 0 \\
\hline
\end{tabular}

AM Ampicillin, C Chloramphenicol, TE Tetracycline, SXT Trimethoprim sulfamethoxazole, CET Cephalothin, CIP Ciprofloxacin, CRO Ceftriaxone, FEB Cefepime, CAZ Ceftazidime, CTX Cefotaxime.

${ }^{2} S, I$ and $R$ Susceptible, Intermediate and Resistant.

${ }^{3}$ MIC Minimum inhibitory concentrations.

${ }^{4} E P$ Egyptian pediatric isolates ( $<5$ years).

${ }_{6}^{5}$ NEP Non-pediatric Egyptian isolates (9-19 years).

${ }_{7}^{6} P$ Pakistan pediatric isolates ( $<5$ years).

() \% of isolates. 


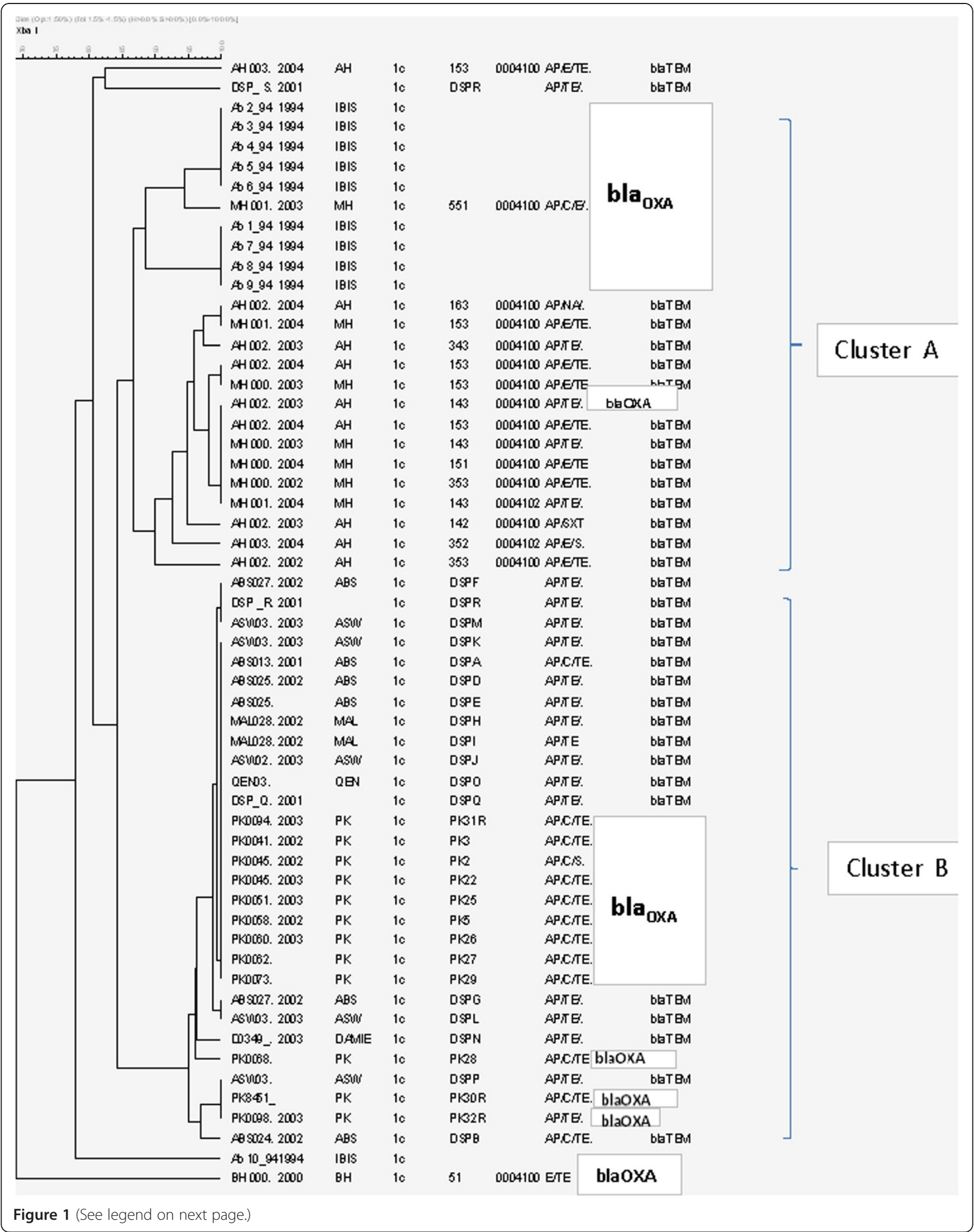


(See figure on previous page.)

Figure 1 The source of the isolate is provided by a two letter code followed by a unique identifying number; an underscore separates the year of isolation from the identifying number. Source abbreviations: AH, Abu Homos, BH, Benha; MH, Mokattum Hills. PK, Pakistan; QEN, ASW, MAL, ABS, P, D, Q,R, S, different regions from upper Egypt and Cairo. Antibiotic resistance profile abbreviations are as follows: AM, ampicillin resistance; $C$, choramphenicol resistance; $\mathrm{E}$, erythromycin resistance; TE, Tetracycline resistance; SXT, trimethoprim-sulfamthoxazole resistance.

Clonal distance is shown after whole genomic digestion using the restriction enzyme xbal. All samples were normalized against the pattern of Salmonella enterica ss. Enterica serotype Braenderup strain H9812. Band pattern analysis was performed using Bionumerics vs 4.5 and dendrogram was calculated using Dice similarity coefficients, based on the unweighted pair group method with arithmetic averages (UPGMA).

ning the protection of human subjects. Species serotypes were determined using commercially available serotyping kits [5], whereas the identity of serotype 1c was confirmed using monoclonal antibodies specific for $S$. flexneri 1 c (MASF) (obtained through the courtesy of Dr. Carlin, 1989). Antimicrobial susceptibility testing (AMS) was performed against 9 types of antibiotics ampicillin (AM, $10 \mathrm{ug}$ ), tetracycline (TE, $30 \mathrm{ug}$ ), trimethoprim-sulphamethoxazole (SXT, $25 \mathrm{ug}$ ), chloramphenicol (C, $30 \mathrm{ug}$ ), ciprofloxacin (CIP, $5 \mathrm{ug}$ ), ceftriaxone (CRO, $30 \mathrm{ug}$ ), cefepime (FEB, $30 \mathrm{ug}$ ), ceftazidime (CAZ, $30 \mathrm{ug}$ ) and cefotaxime (CTX, $30 \mathrm{ug}$ ) by the disk diffusion and E-strips methods as previously described [12]. MDR isolates were defined as those showing simultaneous resistance to at least three antibiotics [5]. Detection of $\beta$-lactam genes was performed by amplifying specific regions of the bla $\mathrm{TEM}_{\mathrm{TEM}}$, bla $\mathrm{SHV}_{\mathrm{SH}}$, and $\mathrm{bla}_{\mathrm{OXA}}$ genes and the mechanism of resistance to sulfa compounds was determined by amplifying the genes sulI and sulII [13]. Testing for class 1 and 2 integrons was also conducted $[13,14]$. Primers were commercially purchased from Sigma-Genosys (St Louis, MO.USA). PCR amplicons were sequenced and confirmed as shown previously [13]. Genomic DNA was prepared to conduct Pulsed Field Gel Electrophoresis (PFGE) [15] using XbaI mrp and the obtained phylogenetic tree was analyzed at a similarity level of $95 \%$ [5].

\section{Availability of supporting data}

High levels of drug resistance were found among and within patient groups in both Egypt and Pakistan (Table 1$)$. The majority of isolates $(\geq 88 \%)$ were resistant to $\mathrm{AM}$ and $\mathrm{TE}$, with expected minimal inhibitory concentrations $>16 \mathrm{ug} / \mathrm{ml}$ [3]. Also, $83 \%$ of PP isolates were resistant to $C(\geq 32 \mathrm{ug} / \mathrm{ml})$, while recent EP and NEP isolates were susceptible. Resistance to SXT was only 20\% in EP 1990-1994 isolates and increased considerably to $88 \%$ in EP 2000-2004 and NEP isolates (89\%) ( $\mathrm{p}>0.05)$. In PP isolates, however, resistance to this drug was $96 \%$. MDR phenotype AM/C/SXT reached $83 \%$ in PP isolates and ranged from 11 to $20 \%$ in EP 1990-1994 and NEP isolates. Other MDR phenotypes (AM/TE/SXT) were found in 79-82\% of EP 2000-2004, NEP and PP isolates. While all isolates from both countries were suscep- tible to CRO, FEB, CAZ and CTX, some (average $=31 \pm$ 35\%) showed resistance to cephalothin.

Of Egypt's EP and NEP AM-resistant isolates, 70\% harbored Bla ${ }_{\text {TEM-1 }}$ resistance gene and the remaining carried $\mathrm{Bla}_{\mathrm{OXA}-1}$ gene. None of the PP isolates harbored the Bla $_{\text {TEM }-1}$ gene while only $52 \%$ of AM-resistant isolates expressed bla OxA-1 gene. The gene sulII was detected in $10 \%$ of EP $1990-1994$ isolates, $53 \%$ of NEP and $65 \%$ of PP isolates. However, it was found in all EP 2000-2004 isolates. The sulI gene was associated with bla $\mathrm{OXA}-1$ gene in $48 \%$ of the isolates. Out of the bla $\mathrm{TEM}_{\mathrm{TEM}}$ positive isolates, $72 \%(23 / 32)$ were positive for class 2 integron and $6 \%$ were positive for class 1 integron. The propor-

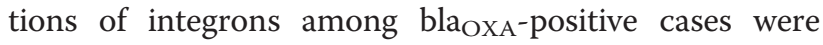
relatively similar. EP and PP isolates that failed to amplify the Bla OXX $_{\text {a }}$ and Bla Bla $_{\text {CTXM, bla }}$ CMY, and bla SHV $_{\text {, }}$ [13]. XbaI mrp-PFGE grouped the majority of isolates in two major clusters; cluster A included $90 \%$ of EP isolates positive for bla OXA and cluster B covered most NEP isolates that harbored

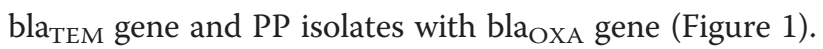

The recent emergence of $S$. flexneri $1 \mathrm{c}$ as a dominant serotype of this species was reported in Southeast Asia and the Indian subcontinent [6-8]. In Egypt, this serotype was identified in three different pediatric populations and their antimicrobial susceptibility patterns demonstrated a trend towards multi-drug resistance, with a dominant resistance phenotype against AM, TE, and SXT. In the present study, more S.flexneri serotype 1c isolates from Egypt were characterized by phenotypic and molecular methods in comparison with a group of isolates obtained from a pediatric study in Pakistan.

While the obtained data may provide a useful baseline for AMS patterns and underlying genes, further studies to evaluate more recent isolates are underway. The high levels of antimicrobial resistance to many drugs in Egypt and Pakistan is in consent with previous reports [16-18] and reflects common medical treatment practices in both countries. Accordingly, CRO has been recommended as a first-line parenteral therapy for children with shigellosis [19] and CIP was used as an alternative when CRO is contraindicated [20,21]. The increased SXT resistance in EP and PP isolates suggests a wider use of SXT treatment during the late 90s in Egypt and Pakistan [18] and exemplifies a dynamic selective drug pressure influence on AMS pat- 
terns [22]. However, a trend towards intermediate resistance to cephalothin has been noticed among all Shigella isolates in this study, which is probably an early alert against the development of resistance to third generation cephalosporins. This observation may suggest leaving this line of drug for empirical use in serious cases of shigellosis only [10]. While EP isolates collected between 1990 and 1994 showed $20 \%$ of MDR phenotype AM/C/SXT, those collected between 2000-2004 demonstrated 82\% of MDR phenotype AM/TE/SXT (Table 1), suggesting that some of the tested drugs may be of limited use as first line therapy [10]. Although little has been known about the prevalence of extended spectrum beta lactamases in S. flexneri serotype 1c isolates, molecular analysis of resistance genes revealed substantial differences among the studied populations with a predominance of $\mathrm{bla}_{\mathrm{TEM}}$ in EP and NEP strains, possibly due to a single gene copy on the large conjugatively transferable plasmid known to endow resistance to AM and SXT [23]. However, the remaining EP isolates carried the bla OXA $_{\text {a }}$ gene, similar to approximately half of the Pakistan isolates (12/23). Previous studies have demonstrated the presence of bla OxA $_{\text {g }}$ gene in AM resistant S.flexneri in different geographic areas including Denmark [24] and Tanzania [25].

In developing countries, SXT is still used as a first-line antibiotic. Yet, $79 \%(55 / 69)$ of the current 1c isolates were resistant to this drug. The dhfria gene which is transferred through a class 2 integron was implicated in SXT resistance [26]. The detection of class 2 integron in $63 \%$ of all isolates probably portrays its role as a mobile element in the dissemination of antibiotic resistance to SXT and C [23]. In the present study, nucleotide sequence analyses revealed that all the bla $\mathrm{OXX}_{\mathrm{A}}$ genes produced OXA-1 type B-lactamase. Interestingly, $88 \%$ of the bla $\mathrm{OXA}^{-1}$ isolates from NPE and PP demonstrated resistance to $\mathrm{C}$, although some studies have reported that $\mathrm{C}$ resistance is chromosomally mediated through the catA1 gene (8). An association between bla OXA-1 gene and AM resistance among Shigella isolates has been documented $[24,25]$ owing to the presence of a class 1 integron that may be placed on the chromosomes to counteract the tendency of losing the virulence/resistance plasmid [8]. However, the susceptibility of isolates to $\mathrm{CRO}, \mathrm{FEB}, \mathrm{CAZ}$ and CTX provides promising treatment options.

Regardless of time, genetic elements mediating resistance and location, XbaI mrp-PFGE profiles placed the majority of S.flexneri 1c isolates in more than one cluster, unlike other S.flexneri serotypes 1b, 2a, 3, 4, and 6 that may show unique clusters for each serotype (5). PFGE grouped 90\% of infant EP isolates collected between 1990 and1994 in one cluster, indicating minor genetic differences. Meanwhile, NEP and PP isolates formed another cluster, probably in relation to age of the patients.
The obtained data highlight the emergence of S. flexneri $1 c$ as an additional serotype in endemic areas. It carries and possibly disseminates drug resistance through variable genetic mechanisms over time and location and should not be overlooked. The spread of multi-resistant strains of this serotype among pediatric and adult populations in endemic areas supports the need for a wiser selection and use of antibiotics. Plans for its proper identification, treatment and control are certainly more urgent than ever.

\section{Consent}

Written informed consent was obtained voluntarily from all adult patients and guardians of children before participation or enrollment in the study in keen for publication of this report.

\section{Abbreviations}

AMS: Antimicrobial susceptibility; MDR: Multi-drug resistance phenotypes; EP: Egyptian pediatric patients; NEP: Egyptian non-pediatric patients; PP: Pakistani pediatric; AM: Ampicillin; TE: Tetracycline; SXT: Trimethoprimsulphamethoxazole; C: Chloramphenicol; CIP: Ciprofloxacin; CRO: Ceftriaxone; FEB: Cefepime; CAZ: Ceftazidime; CTX: Cefotaxime; PFGE: Pulsed Field Gel Electrophoresis

\section{Competing interests}

The authors declare that they have no competing interests.

\section{Authors' contributions}

SFA carried out the molecular genetic studies, wrote the manuscript. JK participated in the design of the study, help in drafting the manuscript, $\mathrm{TH}$ coordinated and helped to draft the manuscript. JM critical revision of manuscript and data content. AN provided final approval for publication. MOW performed data analysis, results interpretation and helped in writing the manuscript. All authors read and approved the final manuscript.

\section{Authors' information}

Co-authors: John Klena, Tupur Husain, Jesse Monestersky, Amel Naguib, Momtaz O Wasfy.

\section{Acknowledgments}

The authors are indebted for Dr. Rumina Hasan for coordinating and providing the Pakistan Shigella isolates. The technical support of Mr. Salem Ibrahim, Abdel-Hakam, and M.Abdel Maksoud is highly acknowledged. Authors are employees of the U.S. Government. This work was prepared as part of their official duties. Title 17 U.S.C. \$105 provides that 'Copyright protection under this title is not available for any work of the United States Government.' Title 17 U.S.C. §101 defines a U.S. Government work as a work prepared by a military service member or employee of the U.S. Government as part of that person's official duties.

The opinions and assertions contained herein are the private ones of the authors and are not to be construed as official or as reflecting the views of the US Navy, US Department of Defense, the United States Government, or the Egyptian Ministry of Health and Population.

The study protocol was supported by DoD\# NAMRU3.2000.0002.

\section{Author details}

${ }^{1}$ Research Science Directorate, United States Naval Medical Research Unit No. 3, Cairo, Egypt. ${ }^{2}$ Department of Epidemiology, Ministry of Health and

Population, Cairo, Egypt

Received: 6 February 2013 Accepted: 14 April 2013

Published: 2 May 2013

\section{References}

1. Ahmed F, Clemens JD, Rao MR, Ansaruzzaman M, Haque E: Epidemiology of shigellosis among children exposed to cases of Shigella dysentery: a multivariate assessment. AmJTrop Med Hyg 1997, 56:258-264. 
2. Ferreccio C, Prado V, Ojeda A, et al: Epidemiologic patterns of acute diarrhea and endemic Shigella infections in children in a poor periurban setting in Santiago, Chile. Am J Epidemio/ 1991, 1134:614-627.

3. Joe LK, Rukmono B, Oemijati S, et al: Diarrhoea among infants in a crowded area of Djakarta, Indonesia. A longitudinal study from birth to two years. Bull World Health Organ 1996, 34:197-210.

4. Kotloff KL, Winickoff JP, Ivanoff B, et al: Global burden of Shigella infections: implications for vaccine development and implementation of control strategies. Bull World Health Organ 1999, 77:651-666.

5. Ahmed SF, Riddle MS, Wierzba TF, Abdel-messih I, Monteville MR, Sanders JW, Klena JD: Epidemiology and genetic characterization of Shigella flexneri strains isolated from three paediatric populations in Egypt (2000-2004). Epidemiol Infect 2006, 134:1237-1248.

6. Kosek M, Yori PP, Olortegui MP: Shigellosis update: advancing antibiotic resistance, investment empowered vaccine development, and green bananas. Curr Opinion Infect Dis 2010, 23:475-480.

7. Stagg RM, Cam PD, Verma NK: Identification of newly recognized serotype 1c as the most prevalent Shigella flexneri serotype in northern rural Vietnam. Epidemiol Infect 2008, 136:1134-1140.

8. Talukder KA, Islam Z, Islam MA, Dutta DK, Safa A, Ansaruzzaman M, Faruque AS, Shahed SN, Nair GB, Sack DA: Phenotypic and genotypic characterization of provisional serotype Shigella flexneri 1c and clonal relationships with $1 \mathrm{a}$ and $1 \mathrm{~b}$ strains isolated from Bangladesh. J Clin Microbiol 2003, 41:110-117.

9. Zafar A, Hasan R, Nizami SQ, Von Seidlein L, Soofi S, Ahsan T, Chandio S, Habib A, Bhutto N, Siddiqui FJ, Rizvi A, Clemens JD, Bhutta ZA: Frequency of isolation of various subtypes and antimicrobial resistance of Shigella from urban slums of Karachi, Pakistan. Int J Infect Dis 2009, 13:668-672.

10. Zafar A, Sabir N, Bhutta ZA: Frequency of isolation of Shigella serogroups/ serotypes and their antimicrobial susceptibility in children from slum areas in Karachi. J Pakist Med Assoc 2005, 55:184-188.

11. Wierzba TF, Abdel-Messih IA, Abu-Elyazeed R, Putnam SD, Kamal KA, Rozmajzl P, Ahmed SF, Fatah A, Zabedy K, Shaheen HI, Sanders J, Frenck R: Clinic-based surveillance for bacterial- and rotavirus-associated diarrhea in Egyptian children. AmJTrop Med Hyg 2006, 74:148-153.

12. Clinical and Laboratory Standards Institute (CLSI): Performance standards for antimicrobial susceptibility testing; twentieth informational supplement Performance standards for antimicrobial susceptibility testing; twentieth informational supplement (document M 100-S20). Wayne, PA; USA: CLSI; 2010. document M 100-S20.

13. Fam N, Leflon-Guibout V, Fouad S, Aboul-Fadl L, Marcon E, Desouky D, El-Defrawy I, Abou-Aitta A, Klena J, Nicolas-Chanoine MH: CTX-M-15-producing Escherichia coli clinical isolates in Cairo (Egypt), including isolates of clonal complex ST10 and clones ST131, ST73, and ST405 in both community and hospital settings. Microb Drug Resist 2011, 17:67-73.

14. El-Gendy AM, Mansour A, Weiner MA, Pimentel G, Armstrong AW, Young SYN, Elsayed N, Klena JD: Genetic diversity and antibiotic resistance in Shigella dysenteriae and Shigella boydii strains isolated from children aged $<5$ years in Egypt. Epidemiol Infect 2012, 140:299-310.

15. Hunter SB, Vauterin P, Mary Ann Lambert-Fair MA, Van Duyne MS, Kubota K, Graves L, Wrigley D, Barrett T, Ribot E: Establishment of a universal size standard strain for use with the PulseNet standardized pulsed-field gel electrophoresis protocols: converting the national databases to the new size standard. J Clin Microbiol 2005, 43:1045-1050.

16. Putnam SD, Frenck RW, Riddle MS, El-Gendy A, Taha NN, Pittner BT, Abu-Elyazeed R, Wierzba TF, Rao MR, Savarino SJ, Clemens JD: Antimicrobial susceptibility trends in Campylobacter jejuni and Campylobacter coli isolated from a rural Egyptian pediatric population with diarrhea. Diag Microbiol Infect Dis 2003, 47:601-608.

17. Putnam SD, Riddle MS, Wierzba TF, Pittner BT, Elyazeed RA, El-Gendy A, Rao MR, Clemens JD, Frenck RW: Antimicrobial susceptibility trends among Escherichia coli and Shigella spp isolated from rural Egyptian paediatric populations with diarrhoea between 1995 and 2000. Clin Microbiol Infect 2004, 10:804-810.

18. Wasfy MO, Oyofo BA, David JC, Ismail TF, el-Gendy AM, Mohran ZS, Sultan Y, Peruski LF Jr: Isolation and antibiotic susceptibility of Salmonella, Shigella, and Campylobacter from acute enteric infections in Egypt. $J$ Heath Popul Nutr 2000, 8:33-38.

19. Eidlitz-Marcus T, Cohen YH, Nussinovitch M, Elian I, Varsano I: Comparative efficacy of two- and five-day courses of ceftriaxone for treatment of severe shigellosis in children. J Pediatr 1993, 123:822-824.
20. Salam MA, Dhar U, Khan WA, Bennish ML: Randomized comparison of ciprofloxacin suspension and pivmecillinam for childhood shigellosis. Lancet 1998, 352:522-527.

21. Guidelines for the control of shigellosis, including epidemics due to Shigella dysenteriae 1. http://whqlibdoc.who.int/publications/2005/9241592330.pdf.

22. McCormick AW, Whitney CG, Farley MM, Lynfield R, Harrison LH, Bennett NM Schaffner W, Reingold A, Hadler J, Cieslak P, Samore MH, Lipsitch M: Geographic diversity and temporal trends of antimicrobial resistance in Streptococcus pneumoniae in the United States. Nature Medicine 2003, 9:424-430

23. Siu LK, Lo JY, Yuen KY, Chau PY, Ng MH, Ho PL: $\beta$-lactamases in Shigella flexneri isolates from Hong Kong and Shanghai and a novel OXA-1-like B-lactamase, OXA-30. Antimicrob Agents Chemother 2000, 44:2034-2038.

24. Schumacher H, Nir M, Mansa B, Grassy A: $\beta$-Lactamases in Shigella. APMIS 1992, 100:954-956.

25. Navia MM, Capitano L, Ruiz J, Vargas M, Urassa H, Schellemberg D, Gascon J, Vila J: Typing and characterization of mechanisms of resistance of Shigella spp isolated from feces of children under 5 years of age from Ifakara, Tanzania. J Clin Microbiol 1999, 37:3113-3117.

26. Toro CS, Farfán M, Contreras I, Flores O, Navarro N, Mora GC, Prado V: Genetic analysis of antibiotic-resistance determinants in multidrugresistant Shigella strains isolated from Chilean children. Epidemiol Infect 2005, 133:81-86.

doi:10.1186/1476-0711-12-9

Cite this article as: Ahmed et al:: Genetic characterization of antimicrobial resistance of Shigella flexneri 1c isolates from patients in Egypt and Pakistan. Annals of Clinical Microbiology and Antimicrobials 2013 12:9.

\section{Submit your next manuscript to BioMed Central and take full advantage of:}

- Convenient online submission

- Thorough peer review

- No space constraints or color figure charges

- Immediate publication on acceptance

- Inclusion in PubMed, CAS, Scopus and Google Scholar

- Research which is freely available for redistribution 